\title{
Rapid Changes of Magnetic Field Polarity in the Late Ediacaran: Linking the Cambrian Evolutionary Radiation and Increased UV-B radiation
}

\author{
Authors: Joseph G. Meert ${ }^{1}$; Natalia M. Levashova ${ }^{2}$, Mikhail L. Bazhenov ${ }^{2,3}$; Ed Landing ${ }^{4}$ \\ Affiliations: \\ ${ }^{1}$ Department of Geological Sciences, 355 Williamson Hall, Gainesville, FL 32611, USA. ${ }^{2}$ Geological Institute, \\ Russian Academy of Sciences, Pyzhevsky Lane, 7, Moscow, 119017 Russia. ${ }^{3}$ Institute of Physics of the Earth, \\ Russian Academy of Sciences, Bolshaya Gruzinskaya st., 10, Moscow, 123242, Russia. ${ }^{4}$ New York State \\ Museum, 222 Madison Avenue, Albany, NY 12230
}

*Towhom correspondence should be addressed: jmeert@ufl.edu

\begin{abstract}
:
Novelty in the biological world is the culmination of genetic changes often triggered by the physical environment. The most radical phase of biological evolution took place during the Cambrian Evolutionary Radiation (CER). Prior to the CER, bacterial matgrounds and associated communities of Ediacaran organisms dominated the shallow seafloor. Near the end of the Ediacaran Period, 550 million years ago, many soft-bodied biota went extinct. In the Early Cambrian, animals with the ability to burrow vertically altered the ecology of the seafloor and biomineralization became commonplace. Here we link the terminal Ediacaran extinction, the Cambrian substrate revolution and the diversification of biomineralizing organisms to changes associated with the reversal frequency of the Earth's magnetic field. Beginning around $550 \mathrm{Ma}$ and continuing through much of the Cambrian, the Earth's magnetic field was rapidly reversing. Models, and limited paleointensity studies, indicate that rapid reversals are a feature of an overall weaker dipole. A weakened dipole reduces the dimensions of the magnetosphere that provides a barrier to incoming cosmic radiation. Here we show that the environmental effects of that collapse include increased dosing of UVB radiation into the shallow marine environment. Increased UVB radiation in the shallow marine environment provided selective pressure favoring organisms that could detect and avoid UVB damage by burrowing vertically, moving up or down in the water column, growing protective shells and other 'flight from light' mechanisms. These changes took place in advance of the CER, but effectively cleared the ecological space for the subsequent changes in the later Cambrian.
\end{abstract}

\section{Introduction}

Biological innovation on the Earth is interconnected with changes in atmospheric composition, hydrospheric modification, eustatic sea level changes, plate tectonic activity, climate change, and other events (e.g., asteroid or comet impacts) that lead to changes in biotic diversity, ecologic interactions, and ultimately to community evolution (Boucot, 1990; Knoll, 2011; Meert and Lieberman, 2008). Arguably, one of the most important periods of biological innovation took place over a relatively short time interval commonly known as the 
"Cambrian Evolutionary Radiation" (CER) that began 542 Ma (Fig. 1). The CER was preceded by the clearing of ecological space during the Kotlinian crisis when several important extinction/radiation events took place coeval with the amalgamation of the southern part of Gondwana (Meert and Lieberman, 2008; Laflamme et al., 2013; Kolesnikov et al., 2015).

The Kotlinian Crisis occurred from about 550-542(?) Ma, during which time many Ediacaran biotic elements went extinct. Diversity in large soft-bodied organisms dropped quickly with the apparent extinction of dickinsoniamorphs, tribachiomorphs and bilateralmorphs and rangeomorphs as well as the extinction of such Ediacaran calcified taxa as Cloudina and Namacalathus (Kolesnikov et al., 2015; Landing et al., 2013; Landing et al., 2015). This extinction overlapped with the development of vertical burrowing that extended below the sediment-water interface and the destruction of bacterial mats as the dominant substrate in shallow to deep marine environments (Bottjer et al., 2000). It also immediately preceeded and overlapped the advent of the primarily aragonitic biomineralization of extant, higher-level metazoan groups (Landing et al., 1989; Zhuralev et al., 2012). Explanations for this transitional interval in the biosphere are legion and include both extrinsic (nonbiological) and intrinsic (biological) triggers (Meert and Lieberman, 2008; Brasier, 1992; Landing et al., 2004; Canfield et al., 2007; Erwin \& Tweedt, 2012; Lenton et al., 2014).

This report proposes that a previously unrecognized, key extrinsic driver of the CER was an interval of frequent magnetic reversals and a resultant weaker magnetic field in the terminal Ediacaran-early Cambrian. Earth was bathed in strong UV-B radiation in the same time interval as a relatively abrupt evolutionary appearance and diversification of higherlevel metazoans took place. These organisms included soft-bodied taxa that burrowed to avoid UV-B and comprised the first infaunal communities as evolutionary stage 1 of the CER (Landing et al., 1989). Somewhat later, stage 2 of the CER featured the appearance and diversification of biomineralized (primarily aragonite) organisms that could withstand not only the high UV-B in the terminal Ediacaran-earliest Cambrian, but used skeletons for shielding against the particularly high UV-B and desiccating conditions at low tide (Landing and Westrop, 2004). 


\section{Magnetic Field Behaviour in the Ediacaran-Cambrian}

From a geophysical perspective, there are equally mysterious questions regarding the nature of plate motions during the Ediacaran. Palaeomagnetic studies in Baltica and Laurentia indicate extremely rapid oscillatory motion from high to low latitudes during the 600-550 Ma interval (Meert et al., 1993; Kirschvink et al., 1997; Meert, 2014). Speculation about the cause of this apparent rapid motion of the continents include true polar wander (Kirschvink et al., 1997), a non-dipolar structure of the Earth's magnetic field (Abrajevitch and Van der Voo, 2010; Gissinger et al., 2012) and a more dynamic mantle (Meert and Tamrat, 2004).

Among the alternative explanations for the apparent rapid polar wander, recent attention has focused on the nature of the Earth's magnetic field during the Ediacaran to Middle Cambrian. Evidence for frequent reversals of the magnetic field during this interval come from studies in Siberia (Pavlov and Gallet, 2000; Gallet et al., 2003; Shatsillo et al., 2015), Baltica (Levashova et al., 2013; Meert, 2014; Bazhenov et al., 2016) and China (Yin, 2002). The geomagnetic reversal rate in the Zigan Formation ( 550 Ma, Russian southwestern Urals) is conservatively estimated at $24 \mathrm{RMa}^{-1}$ (reversals per mega-annum) compared to a maximum of 8-10 $\mathrm{RMa}^{-1}$ in the Phanerozoic (Biggin et al., 2012). Highfrequency of reversals was also noted in the Winter Coast Region at 550 Ma although a specific reversal rate was not calculated (Popov et al., 2005; figure 2a,b).

The Lopata Formation (555-540 Ma) in SW Siberia contains at least fifteen magnetozones in a $\sim 45$-meter thick sequence that was deposited in $\sim 1$ Ma (Shatsillo et al., 2015). Using the age constraints cited in that study and the number of reversals, the rocks in SW Siberia indicate a reversal rate of $15 \mathrm{RMa}^{-1}$.

In the younger Middle Cambrian Khorbusuonka and Kulyumbe River sections of northwest Siberia the reversal rate was $4-8 \mathrm{RMa}^{-1}$ for the time period from 510-500 Ma (Pavlov and Gallet, 2000; Gallet et al., 2003; Figure 3). A more comprehensive analysis of the Kulyumbe river section yielded a slightly higher reversal rate of $10 \mathrm{RMa}^{-1}$ for the Middle Cambrian (Kouchinsky et al., 2008). The magnetostratigraphy in the Yuanshan Member of the Chuingchussu Formation containing the Chenjiang lagerstatte indicated a minimum of 29 polarity reversals (Yin, 2002). The Chuingchussu section would be equivalent to the 
lowermost part of Epoch $2(\sim 520 \mathrm{Ma})$ and may extend the hyperactive reversal interval down to the Terreneuvian-Epoch 2 boundary.

There are other Ediacaran-Cambrian palaeomagnetic studies relevant to this article that do not report specific reversal rates, but have unique signatures that may indicate magnetic field hyperactivity. The $508 \mathrm{Ma}$ Carion granite in Madagascar shows several phases of emplacement with at least 3 polarity intervals recorded in the granite (Meert et al., 2001). Stratoid granites (521 Ma) within the virgation zone of central Madagascar show multiple polarities (Meert et al., 2003). The 547 Ma Sinyai dyke in Kenya shows a dualpolarity magnetization in a single dyke (Meert et al., 1996). Fewer results are available from Terreneuvian and Lower Epoch 2 sequences, but they seem to show a lower rate of reversals than the preceding or subsequent Cambrian intervals (Kirschvink et al., 1991). Additional work needs to be carried out on the Early Cambrian reversal pattern to see if the rapid reversal pattern dominates for the entire 550 to $497 \mathrm{Ma}$ interval or if there is a short period in the Lower Cambrian with a lower reversal rate. A palaeomagnetic study of the Grenville dykes in Laurentia did not yield a specific rate for reversal frequency at 585 Ma because the study was based on intrusive rocks that were injected irregularly in time. That study showed apparently rapid migration of Laurentia from polar latitudes to equatorial latitudes that is inexplicable using reasonable mantle viscosities. The authors concluded that the dykes had sampled transitional fields (equatorial dipoles) during a period of rapid reversal frequency (Halls et al., 2015).

The available palaeomagnetic data cited above indicate that reversal frequency during the Ediacaran-Cambrian interval from $(\sim 550-500)$ was punctuated by periods of magnetic field hyperactivity followed by a long non-reversing state in the Ordovician. The so-called Moyero Reverse epoch occurred during the Ordovician from 480-460 Ma (Pavlov and Gallet, 2005; figure 3a). During the past $160 \mathrm{Ma}$, reversal rates are highly variable, but the most frequent averages (calculated over a 10 million year moving window) are around 2-3 $\mathrm{RMa}^{-1}$ (Biggin et al., 2012). We therefore refer to a hyperactive reversal state when the frequency is above $4-6 \mathrm{RMa}^{-1}$ (e.g. twice the background value). While research is still controversial, there is evidence to suggest that during a time of frequent magnetic reversals, the dipole component of the Earth's magnetic field is weaker than during periods when the 
polarity of the magnetic field does not change (Biggin et al., 2012, Valet et al., 2005; Tauxe et al., 2013). During a magnetic reversal, the dipole component of the field decays and then intensifies in the opposite direction while the quadrupolar component of the field becomes dominant with significantly lower strength. In this paper, we discuss links between magnetic field reversal hyperactivity, a low magnetic dipole strength, destruction of a young ozone layer and the biological changes during and shortly after the Kotlinian crisis.

\section{Magnetic Field Strength and UV-Shielding}

A low dipole intensity can cause a decrease in the position of the magnetopause relative to the Earth's atmosphere. The magnetopause marks the theoretical boundary where the pressure of the heliospheric wind is equal to the force of the Earth's magnetic field. The normal 'shielding distance' provided by the Earth's dipolar field extends out to about 10 Er (Earth radii), but during a reversal, this distance may shrink to only 1.3-1.8 Er (Wei et al., 2014; Figure 4a). It is also important to note that the energy of the solar wind (solar pressure) would have been some 1.3-1.5 times stronger during the Ediacaran resulting in a contracted magnetosphere (Wood et al., 2002; Svensmark, 2006). As the distance between the magnetopause and the Earth's atmosphere shrinks, the particle flux to the upper atmosphere of the Earth increases due to the loss of shielding (Shea et al., 2004; Vogt et al., 2007).

There are three potential sources of energetic particles that can interact with the atmosphere of the Earth. The most common are solar particles (solar wind) that constantly bombard the Earth. Solar proton events (SPEs) may cause a temporary increase in the energy and density of interactions and occur during solar storms. The storms are less common, but occur on a fairly regular basis during a normal $\sim 11$-year solar cycle with very large "Carrington-type" events being less frequent (Nymmik, 2011; Riley, 2012). The impact on the Earth's atmosphere during these storms is short-lived; however, because of their frequency, there can be a cumulative effect on an Earth with a weaker dipolar field and frequent reversals (Wei et al., 2014).

The second, more infrequent source of energetic particles is from 'nearby' gamma ray bursts (Horvath, 2003; Melott et al., 2004). Gamma ray bursts (GRBs) occur during the collapse of large stars when particles are explosively ejected along two narrow jets. The energy of particles produced in GRBs that reach the Earth are much stronger than SPEs and 
the effects are longer lasting (up to tens of years). The last, and perhaps most devastating possibility is from the passage of our solar system through an interstellar cloud (Pavlov et al., 2005).

The effects of GRB photons are two-fold. First, they may cause similar upper atmospheric effects to those of SPEs. Because of their high energy (as compared to SPEs), GRB photons can also penetrate the entire atmosphere and reach the marine environment where they can cause DNA damage to unprotected organisms (Horvath, 2003; Chen and Ruffini, 2014). The rate of GRB events is more difficult to assess (Melott et al. 2004). Gammaray bursts are thought to occur 1-5 times per million years, but very large Earth proximity bursts are more infrequent (Horvath, 2003; Melott et al., 2004, Svensmark, 2006. Gammaray energy is highly focused in twin beams from the collapsing star. Thus, not only must the GRB occur nearby, but the 'beams' must be focused in the direction of the Earth. The Late Ordovician mass extinction, for example, has been attributed to the environmental effects of a nearby gamma-ray burst (Melott et al., 2004).

The anomalous component of galactic rays (ACRs) refers to neutral particles contained in interstellar clouds. As our solar system moves through the cloud, the neutral particles become ionized and accelerated by the solar wind. The main ACRs found in interstellar clouds are nitrogen, oxygen, neon, argon, carbon, hydrogen and helium. The effect of ACRs on the upper atmosphere are the same as gamma rays and SPEs in that they reduce ozone via catalytic reactions with $\mathrm{NO}_{\mathrm{x}}$. The main difference is that ACRs will continue to be produced during the entire passage of our solar system through the interstellar cloud. That passage may take as long as 1 million years.

All three 'events, SPEs, GRBs and ACRs can reduce levels of ozone and oxygen in the atmosphere (figure 4a,b). The reduction is exacerbated when the Earth's magnetic field strength is reduced or altered. A weakened dipole, constricted magnetopause and higher solar pressure would allow $\mathrm{O}_{2}$ to become disassociated and ionized during particle bombardment from SPEs, GRBs and ACRs. Following ionization, $\mathrm{O}^{+}$ions can escape into interplanetary space (figure 4a; Wei et al., 2014). Mars is thought to have been stripped of its atmosphere due to its lack of a strong magnetic field and interactions with solar particles. The total magnitude of the $0+$ loss to interplanetary space (during a reversal) will increase $3-4 x$ the normal rate in the absence of any SPEs (Wei et al., 2014). 
Interactions between incoming radiation and nitrous oxide particles $\left(\mathrm{NO}_{\mathrm{x}}\right)$ can remove ozone from the upper atmosphere (figure 4 b; Portmann et al., 2014). The magnitude of ozone loss has been modeled for SPE, GRB and ACR events (Wei et al., 2014; Pavlov et al., 2005; Vogt et al., 2007; Winkler et al., 2008). ACR events result in the most widespread destruction of the ozone layer. During an active ACR period, ozone is lowered by $40 \%$ globally and up to $80 \%$ at the polar regions (Pavlov et al., 2005). This decrease can persist for up to 10,000 years or more. GRBs can also result in significant decreases in $\mathrm{O}_{3}$ levels in the upper atmosphere. There are difficulties in assessing the magnitude of $\mathrm{O}_{3}$ loss because the $\mathrm{NO}_{\mathrm{x}}$ reactions can become self-limiting and the direction and magnitude of the GRB must be taken into account (Melott et al., 2004). Nevertheless a 10-30\% decrease in global ozone levels can cause considerable disruption to living organisms exposed to increased UV-B flux. As an example, a $40 \%$ decrease in $0_{3}$ levels in the upper atmosphere results in a $\sim 200 \%$ increase in the biologically effective radiation dosage on the surface of the Earth (Cockell and Blaustein, 2001; Pavlov et al., 2005). Solar events, while far more common, have the smallest effect on ozone depletion. Models indicate that quadrupoles, equatorial dipoles and octupolar fields can change the region and magnitude of ozone depletion in the upper atmosphere and affect all latitudinal bands. These types of magnetic field structures are likely to be encountered during reversals of the main field. An overall weaker dipole field results in a significant ozone depletion at high latitudes that could last for several months to years. Ozone depletion during a reversal could reach up to $30 \%$ at higher latitudes and persist for the 7,000-10,000 year duration of the reversal (Winkler et al., 2008; Vogt et al. ,2007).

Both GRBs and ACR events occur stochastically and thus it is difficult to establish a geohistorical narrative for any particular interval of time. In spite of their stochastic nature, there have been studies that attempt to link astronomical events to biological extinctions or radiations including the CER (Wei et al., 2014; Melott et al., 2004; Lieberman and Melott, 2007; Cockell, 1999; Horvath, 2003; Chen and Ruffini, 2014).

While the likelihood of a focused GRB or ACR encounter during the EdiacaranCambrian interval from $\sim 550-500 \mathrm{Ma}$ is non-zero, it is difficult to establish this probability with any certainty. Estimates for the frequency of an extremely large and harmful GRB flux is two (or more) per billion years (Wei et al., 2014; Horvath, 2003; Pavlov et al., 2005). ACR 
encounters are thought to be more frequent with 7-8 passages in the past $250 \mathrm{Ma}$ ( $\sim 1$ every 30-35 Ma; Pavlov et al., 2005). Our discussion below therefore considers SPEs as the main driver of ozone (and oxygen) depletion during the Late Ediacaran. During the past 20 or so solar cycles, there have been very large Carrington events and also periods of minimal activity (Maunder minima; Nymmik, 2011; Riley, 2012). It is important to put both the largest events and smallest events in proper context. The historical record of solar activity extends back only a few hundred years and even though very large SPEs are rare, over the 50 Ma span of the Ediacaran-Cambrian, they are expected to be quite frequent.

\section{Ozone, Oxygen and Biological Responses}

Extant biological organisms respond to increased UV-B radiation via ecologic and evolutionary adaptations that include repair mechanisms, behavioural changes, and morphological/structural innovations. These adaptations include, but are not limited to: genetic repair from UV damage; diel vertical migration (up or down through the water column); masking behaviour and burrowing (Phoenix et al., 2001; Sigg et al., 2007; Bebout and Garcia-Pichel, 1995; Hader et al., 2007). Given that even a modest reduction in ozone can result in a significant increase in DNA damage, we postulate that the Kotlinian Crisis and the subsequent innovations and diversifications of biomineralized organisms and vertical burrowing are evolutionary developments linked to lower $\mathrm{O}_{3}$ levels and a rapidly reversing magnetic field. Although evidence for an unstable magnetic field is hinted at during the 600$550 \mathrm{Ma}$ interval, there are few, if any, detailed magnetostratigraphic studies detailing its structure. We therefore confine our arguments to the interval from 550-500 Ma where a number of magnetostratigraphic studies indicate reversal rates between 6-24 $\mathrm{RMa}^{-1}$.

While it is generally agreed that atmospheric oxygen levels (along with deep ocean and shallow ocean oxygen levels) reached Phanerozoic modulation levels early in the Palaeozoic, the exact timing, structure and dynamics of that rise is still a matter of debate (Lenton et al., 2014; Berner, 2009; Sperling et al., 2013; Clapham et al., 2003). For this report, we propose that atmospheric oxygen levels around 550 Ma were somewhere less than $15 \%$ and may have dropped from more modern-day levels (21\% or higher) at $585 \mathrm{Ma}$ (Berner, 2009). Against this backdrop of falling atmospheric $\mathrm{O}_{2}$, we argue that there was an increased

incidence of ultraviolet radiation reaching shallow marine levels due to an overall weak, and rapidly reversing, magnetic field. An alternative interpretation of Ediacaran-Cambrian 
oxygen levels is that a "modern" ocean with essentially modern levels of oxygenation existed by the terminal Ediacaran, a proposal indicated by the presence of oxygenated sediments (i.e., red and purple mudstones) and large Ediacaran organisms in deep slope facies, while new data on Cambrian isotopes question widespread low oxygen conditions in the ocean (Clapham et al., 2003; Landing, 2012; Fike et al., 2006; Wotte and Strauss, 2015). The hyperactive interval ended during the Furongian Epoch ( $497 \mathrm{Ma})$ where reversal rates decreased below $6 \mathrm{RMa}^{-1}$. The end of hyperactivity may be marked by an increase in atmospheric oxygen levels at this same time (figure 3b; Saltzmann et al., 2011).

One of the more important changes in the biosphere was the so-called "Cambrian substrate revolution" (Bottjer et al., 2000; Meysman et al., 2006). The substrate revolution marked a major change in the behaviour of organisms with respect to the sediment-water interface. During the Ediacaran interval (preceding the Kotlinian Crisis), bioturbation was dominated by horizontal burrowing along and underneath the ubiquitous microbial mat structures at the sediment-water interface (Kolesnikov et al., 2015; Bottjer et al., 2000). Following the Kotlinian Crisis and into the Early Cambrian, organisms began to penetrate the sediment water interface by (initially) burrowing through the microbial mats. This ecosystem engineering is thought to be one of the major causes for the destruction of laminated microbial matgrounds as the dominant facies of the shallow and deep sea-floor and the transition to unstable substrates of the subsequent CER (Kolesnikov et al., 2015). While the transition from a laminated, relatively plastic bacterial matground to a vertically burrowed, unstable or soft-ground substrate is well-supported, the underlying driving force for this change remains enigmatic.

Studies on the biological effects of elevated UV-B radiation due to the emission of chlorofluorocarbon compounds has led to a wealth of knowledge regarding mortality rates, evolutionary adaptations and behavioural adaptations of marine organisms subjected to higher incident UV-B radiation in shallow environments (Rawlings, 1996; Garcia-Pichel, 1998; Rozema et al., 2002; Hader et al., 2007; Llabres et al., 2013). Tedetti and Sempere (2006) reviewed the effective UV-B radiation dosing in a variety of marine environments (open ocean, coastal and Antarctic) and found that the depth of penetration was dependent on dissolved organic content and sediment input. In shallow marine environments penetration depths ranged between 0.2-16 meters. Garcia-Pichel and Bebout (1996) noted 
that UV-B exposure on bacterial matgrounds in shallow marine environments depends not only upon the optical properties of the water column, but also on the properties of the underlying sediments. They discovered important UV-B radiation dosing enhancement within the mats.

Modern-day observations of microbial mats in Egypt and Venezuela provide some hints as to the relationship between the structure of the mats and the cyanobacteria that live in and are dominant producers of the mats (Gingras et al., 2011; Vinebroke and Leavitt, 1999). Experiments show color changes within the mat when exposed to UV-B radiation along with a downward migration of the main photosynthetic zone. The vertical migration of cyanobacteria also moves the $\mathrm{O}_{2}$ production downward within the mat and provides the cyanobacteria with an additional filter from UV-B radiation (Bebout and Garcia-Pichel, 1995; Hader et al., 2007; Gingras et al., 2011). Vertical migration through the mat surface could lead to three potential benefits for mobile organisms. These include access to a food source, oxygen mining within the mat and UV-B avoidance (Bebout and Garcia-Pichel, 1995; Gingras et al., 2011; Llabres et al., 2013; Rhode et al., 2001). Studies of modern zoobenthos in high elevation lakes show that motility and the ability to seek refuge from UV-B radiation is an effective strategy (Vinebroke and Leavitt, 1999). Vertical diel migration in response to UV$B$ radiation levels is also well known in a number of marine organisms (Hader et al., 2007).

We argue that the combination of lower ozone and higher incident radiation resulted in the extinction of mostly sessile Ediacaran organisms and favored the rise of organisms that were able to burrow vertically or had protective adaptations to survive DNA damage from UV-B radiation. This appearance and diversification of metazoans that produced deep and behaviourly complex burrows has been regarded as the first stage of the Cambrian Evolutionary Radiation (Landing et al., 2013; Landing et al., 1989). Sessile, soft-bodied organisms have no 'escape' mechanism from UV radiation. Unless, pre-existing genetic information is present in the organism to repair DNA damage from UV-radiation, the likely rates of individual organism death and taxonomic extinction are high. There is little information regarding the genetic makeup of the Ediacaran fauna; although there are numerous inferences as to the lifestyle and rationale for the end Ediacaran extinction (McCall, 2007; Xiao and Laflamme, 2008, Darroch et al., 2015). While some of the forms may have limited mobility, many appear to be sessile forms that were attached to matground 
surfaces in shallow and deep ocean bottoms. Even organisms with limited motility appear to be intimately associated with bacterial matgrounds. When the matground habitat was destroyed through burrowing, the ecological communities associated with the matground and the laminated matground lithofacies disappeared. These earlier communities and lithofacies were replaced by Phanerozoic-aspect communities that included sediment consumers along with burrowing predators and prey that produced weakly to thoroughly burrow-homogenized bottom sediments (Darroch et al., 2015).

The second stage of the CER included the diversification (and probable origin) of metazoan communities dominated by biomineralized protostomes (e.g., mollusks and hyoliths, among other organisms) that lived on the substrate. As noted above, these mineralized skeletons were primarily calcareous with aragonite being the "favored" early mineral, although silica (in sponges) has an early appearance and a few problematical conoidal taxa, tommotiids, and somewhat later appearing linguloid brachiopods used phosphatic minerals.

A biomineralized external skeleton provided a number of advantages to metazoans in the second stage of the CER. Hard shells obviously provide protection against predators, serve as a biochemical mechanism for removing toxins, and provide protection from UV-B radiation (Rowland and Gangloff, 1988; Quintero-Torres et al., 2006). The earliest recorded occurrences of biomineralized taxa were in the shallowest (i.e., peritidal or intertidal) facies preserved on the Avalonia paleocontinent in eastern Newfoundland, Nova Scotia, and New Brunswick (Landing and Westrop, 2004). These early appearing taxa progressively migrated offshore in the Early Cambrian into somewhat more offshore facies dominated by softbodied burrowing organisms. The earliest recorded occurrence of a number of high-level protostome taxa in peri- or intertidal facies was equated with the loci of origin of the oldest gastropods, rostroconchs, orthothecids, eccentrothecimorph tommotiids, pseudoconodonts, and halkierids of Cambrian evolutionary stage 2 . The interpretation is that the appearance of mineralized shells allowed metazoans to colonize the hostile, peri- or intertidal habitat as shells decreased the possibility of desiccation and ultraviolet damage at low tide (Landing and Westrop, 2011). The protection afforded by mineralized shells allowed appearance of these first intertidal communities early in the CER. These early protostomes are then joined 
somewhat later in the peritidal facies by the earliest appearing linguloid brachiopods and protoconodonts.

The appearance of intertidal communities may have meant the colonization of a previously largely metazoan-free habitat which, as it lacked the large off-shore burrowers, likely had a harder substrate that mollusks could cling to and lacked large, soft-bodied predators.

The Sun has always been a powerful force in the development of life on Earth. Early cyanobacteria were bathed in UV-B radiation during the Archean (the first UV crisis; GarciaPichel, 1998; Cockell and Raven, 2007). It is likely that the first photoreceptors were developed at that time (Gehring and Roshbash, 2003). The second UV crisis might well have occurred late in the Ediacaran and persisted into the earliest Cambrian as oxygen and ozone were lost from the atmosphere due to the unusual structure of the Earth's magnetic field. Photosensitivity would be advantageous for organisms to orient themselves towards/away from the light. Certainly, the eye afforded many other advantages in predator/prey relationships and sexual reproduction, but it developed as a result of light sensitive genes. It is therefore possible that the second UV crisis also provided the selective pressure to develop more complex photosensitive organs, the 'flight from light,' and the first circadian rhythms (Gehring and Roshbash, 2003).

\section{Triggering a Hyperactive Magnetic Field}

We close with possible conjectures as to why the Earth's magnetic field was hyperactive during the Ediacaran-Cambrian interval. The nucleation of the inner core is thought to provide a stabilizing effect on the geodynamo (Hollerbach and Jones, 1995; Aubert et al., 2010). At issue, is that any attempt to determine the age of the inner core requires knowledge of the heat flux at the core-mantle boundary (and its evolution), the composition of the inner core, and the presence/type of radioactive elements in the core (Labrosse et al., 2001; Gomi et al., 2013). None of these parameters are well constrained and therefore it is no surprise that the 'best guess' for the initiation of inner core nucleation is given as $1.0 \pm 0.5 \mathrm{Ga}$ (Labrosse et al., 2001). Thus, it is possible that inner core nucleation began during the Late Ediacaran or alternatively, that the inner core grew past some critical size that led to instabilities in the geodynamo. 
Other research indicates that reversal frequency may be directly related to plate tectonics, variability in core heat flux, or whole mantle convection processes (Biggin et al, 2012; Petrelis et al., 2011; Driscoll and Olson, 2011). Plate tectonics is thought to result in a high reversal rate following intervals in Earth history when the Earth's continents are asymmetrically distributed about the equator (Biggin et al., 2012). The difficulty in applying this model to the Ediacaran is that we have very little control on palaeogeographic reconstructions in the 650-550 Ma interval, but a traditional reconstruction at $\sim 530 \mathrm{Ma}$ does show a marked asymmetry that may persist well into the Moyero reverse interval (Meert and Lieberman, 2008). Alternatively, there are models positing a more symmetrical distribution during the Cambrian with many of the continents in the tropical zone (Landing et al., 2013). It is intriguing to note that these hyperactive periods occur during the breakup of Pannotia and assembly of Gondwana (550 Ma), the assembly of Pangea (Carboniferous) and the dispersal of Pangea. These tectonic transitions are separated by $\sim 180-200 \mathrm{Ma}$ intervals.

A second conjecture suggests that an increase in core heat flux drives the modeled geodynamo from a superchron state to reversing behavior (Biggin et al., 2012). In this model, core heat flux is correlated with reversal frequency, dipole variability and relative strength of the non-dipole field. Rapid reversals occur as the dipole field collapses and the strength of the dipole is low. In addition to modeling the flux across the core-mantle boundary (CMB), it was noted that the decrease in CMB flux leading to a non-reversing state may be linked to mantle processes such as reduced mantle plume production or an episode of true polar wander (Biggin et al., 2012).

There have been suggested episodes of true polar wander (TPW) or rapid plate motion in the Ediacaran-Cambrian (Kirschvink et al., 1997; Meert and Tamrat, 2004). TPW episodes, if borne out by future data, would support the argument that links TPW to magnetic field hyperactivity (Biggin et al., 2012). It is also an intriguing observation that an overall trend in reversal frequency shows a ramp up into a hyperactive mode (Ediacaran and Jurassic) followed by a decay in reversal frequency leading into the superchrons (Moyero and Cretaceous Long Normal (Biggin et al., 2012; Pavlov and Gallet, 2005). Whether or not this ramp/decay is a real reflection of geodynamo activity remains to be seen. If correct, we would predict an interval of magnetic field hyperactivity in the Devonian or Mississippian in 
advance of the 262-318 Ma Kiaman Reverse superchron (figure 5a,b). Recently published data from the Frasnian-Fammenian boundary section ( $\sim 372 \mathrm{Ma}$ ) in the Canning Basin of Australia yields a reversal rate of 5-6 RMa-1 (Hilbun et al., 2015; Hansma et al., 2015).

A robust feature of reversal models is that a rapidly reversing magnetic field is correlated with an overall lower dipole strength (Amit et al., 2010). A weaker dipole results in a constriction of the magnetosphere and increases the potential of atmospheric decreases in both oxygen and ozone. Atmospheric oxygen levels in the late Ediacaran ( $550 \mathrm{Ma})$ and through the Furongian ( $\sim 497 \mathrm{Ma}$ ) remained at around 15\% (Saltzman et al., 2011). Oxygen levels increased in the Furongian at approximately the same time that magnetic field reversal frequency began to decline. This correlation is suggestive of a close link between atmospheric oxygen levels and magnetic field strength (Wei et al., 2014).

Conclusions

Our conclusion emphasizes the temporal correspondence of terminal EdiacaranEarly Cambrian geodynamic events and a major replacement of biotas that led to the appearance of Phanerozoic higher-level taxa and ecological communities in the marine realm. We link not only the terminal Ediacaran Kotlinian extinction but the Cambrian substrate revolution of soft-bodied metazoan, as well as the origin and diversification of biomineralized metazoans that comprise the second stage of the CER, primarily to increased dosing of living organisms with UV-B radiation as a direct result of the weaker dipole. The clearing of this ecological space and ecosystem engineering lead to the increase in diversity noted in the CER.

Acknowledgements: We wish to thank the editor of GR and a number of informal and formal reviews of this paper for improving the final version. JGM wishes to acknowledge support from the US National Science Foundation grant EAR11-19038. The conclusions in this paper are the sole responsibility of the author and do not reflect those of the National Science Foundation. This study was funded by grants 12-05-00513 (M. Bazhenov) and 11-05-00037 (N. Levashova), from the Russian Foundation of Basic Research and grant 14.Z50.31.0017 of the Government of the Russian Federation.

\section{References:}

Abrajevitch, A., Van der Voo, R., 2010. Incompatible Ediacaran palaeomagnetic directions suggest an equatorial geomagnetic dipole hypothesis. Earth and Planetary Science Letters, 293, 164-170.

Amit, H., Leonhardt. R., Wicht, J., 2010 Polarity reversals from palaeomagnetic observations and numerical dynamo simulations, Space Science Reviews, 155, 1-43. 
Aubert, J., Tarduno, JA., Johnson, C.L., 2010. Observations and models of the longterm evolution of the Earth's magnetic field, Space Science Reviews, doi:10.1007/s11214-010-9684-5.

Bazhenov, M.L., Levashova, N.M., Meert, J.G., Golovanova, I.V., Danukalov, K.N., Federova, N.M., 2016. Late Ediacaran magnetostratigraphy of Baltica: Evidence for magnetic field hyperactivity? Earth and Planetary Science Letters, 435, 124-135

Bebout, B.M. and Garcia-Pichel, F., 1995. UV B-induced vertical migrations of cyanobacteria in a microbial mat, Applied Environmental Microbiology, 61, 42154222.

Berner, R.A., 2009. Phanerozoic atmospheric oxygen: new results using the GEOCARBSULF model, American Journal of Science, 309, 603-606.

Biggin, A.J., B. Steinberger, J. Aubert, N. Suttie, R. Holme, T.H. Torsvik, D.G. van der Meer, and D. J. J. van Hinsbergen, 2012. Possible links between long-term geomagnetic variations and whole-mantle convection processes, Nature Geoscience, $5,526-533$.

Bottjer, D.J., Hagadorn, J.W., Dornbos, S.Q., 2000. The Cambrian substrate revolution, GSA Today, 10, 1-7.

Boucot, A.J., 1990. Evolution of communities. In: Briggs, D. E. G., Crowther, P.R. (eds.), Palaeobiology: A Synthesis. Blackwell Scientific Publications, Oxford, 391394.

Bowring, S.A., Grotzinger, J.P., Isachsen, C.E., Knoll, A.H., Pelechaty, S.M., Kolosov, P., 1993. Calibrating rates of Early Cambrian evolution, Science, 261, 1293-1298

Brasier, M.D., 1992. Background to the Cambrian explosion, Journal of the Geological Society of London, 149, 585-587.

Canfield, D.E., Poulton, S.W., Narbonne, G.M., 2007. Late-Neoproterozoic deep-ocean oxygenation and the rise of animal life, Science, 315, 92-95.

Clapham, M.E., Narbonne, G.M., Gehling, J.G., 2003. Paleoecology of the oldest known animal communities at Mistaken Point, Newfoundland. Paleobiology, 29, 527-544.

Chen, P. \& Ruffini, R., 2014. Did gamma ray burst induce Cambrian explosion? Astrophysical Abstracts, arXiv1403.7303v1, 4 p.

Cockell, C.S., 1999. Crises and extinction in the fossil record- a role for ultraviolet radiation?, Paleobiology, 25, 212-225.

Cockell, C.S. \& Blaustein, A.R., 2001. Ecosystems, Evolution and Ultraviolet radiation, Springer Publications, New York, $226 \mathrm{pp}$. 
Cockell, C.S. and Raven, J.A., 2007. Ozone and life on the Archean Earth, Philosophical Transactions of the Royal Society-A, 365, 1889-1901.

Darroch, S.A.F., Sperling, E.A., Boag, T.H., Racicot, R.A., Mason, S.J., Morgan, A.S., Tweedt, S., Myrow, P., Johnston, D.T., Erwin, D.A., Laflamme, M., 2015, Biotic replacement and mass extinction of Ediacaran biota, Procedings of the Royal Society Biology, 282, doi:10.1098/rspb.2015.1003

Driscoll. P., Olson, P., 2011. Superchron cycles driven by variable core heat flow, Geophysical Research Letters, 38, doi:10.1029/2011GL046808 (2011)

Erwin, D., Tweedt, S., 2012. Ecological drivers of the Ediacaran-Cambrian diversification of Metazoa, Evolutionary Ecology, 26, 47-433.

Fike, D.A., Grotzinger, J.P., Pratt, L.M., Summons, R.E., 2006. Oxidation of the Ediacaran Ocean. Nature 144, 744-747.

Gallet, Y., Pavlov, V., Courtillot, V., 2003. Magnetic reversal frequency and apparent polar wander of the Siberian Platform in the earliest Palaeozoic, inferred from the Khorbusuonka river section (northeastern Siberia), Geophysical Journal International, 154, 829-840.

Garcia-Pichel, F., 1998. Solar ultraviolet and the evolutionary history of cyanobacteria, Origins of Life and Evolution of the Biosphere, 28, 321-347.

Garcia-Pichel, F. ad Bebout, B., 1996. Penetration of ultraviolet radiation into shallow water sediments: high exposure for photosynthetic microbial communities, Marine Ecology Progress Series, 131, 257-262.

Gehring, W.J., Roshbash, M., 2003. The coevolution of blue-light photoreception and circadian rhythms, Journal of Molecular Evolution, 57, S286-S289.

Gingras, M., Hagadorn, J.W., Seilacher, A., Lalonde, S.V., Pecoits, E., Petrash, D., Konhauser, K.O., 2011. Possible evolution of mobile animals in association with microbial mats, Nature Geosciences, 4, 372-375.

Gissinger, C., Petitdemange, L., Schrinner, M., Dormy, E., 2012. Bistability between equatorial and axial dipoles during magnetic field reversals, Physical Review Letters, 108, 234501-1 - 234501-4.

Gomi, H., Ohta, K., Hirose, K., Labrosse, S., Caracas, R., Versdtraete, M.J., Hernlund, J.W., 2013. The high conductivity of iron and thermal evolution of the Earth's core, Physics of the Earth and Planetary Interiors, 224, 88-103. 
Grazhdankin, D.V., V.V. Marusin, J. Meert, M.T. Krupenin, A.V. Maslov, 2011. Kotlin Regional Stage in the South Urals, Doklady Earth Sciences, 440, 1222-1226

Hader, D-P, Kumar, H.D., Smith, R.C. and Worrest, R.C., 2007. Effects of solar UV radiation on aquatic ecosystem and interactions with climate change, Photochemistry and Photobiological Science, 6, 267-285.

Halls, H.C. Lovette, A., Hamilton, M., Soderlund, U., 2015. A palaeomagnetic and U-Pb geochronology study of the western end of the Grenville dyke swarm: Rapid changes in palaeomagnetic field direction at ca. 585 Ma related to polarity reversals, Precambrian Research, 257, 137-166.

Hillbun, K., Playton, T.E., Tohver, E., Ratcliffe, K., Caulfield-Kerney, S., Wray, D., Haines, P., Hocking, R., Katz, D., Montgomery, P., Ward, P., 2015. Upper Kellwaser carbon isotopic excursion pre-dates the Frasnian-Fammenian boundary in the upper Devonian Lennard Shelf carbonate system, Canning Basin, western Australia, Palaeogeography, Palaeoclimatology, Palaeoecology, doi:10.1016/j.paleo.2015.07.035.

Hansma, J., Tohver, E., Yan, M., Trinajstic, K., Roelofs, B., Peek,S., Slotznik, S.P., Kirschvink, J., Playton, T., Haines, P., Hocking, R., 2015. Late Devonian carbonate magnetostratigraphy from the Oscar and Horse Spring Ranges, Leonard Shelf, Canning Basin, Western Australia, Earth and Planetary Science Letters, 409, 232242.

Hollerbach, R., Jones, C.A., 1995. On the magnetically stabilizing role of the Earth's inner core, Physics of the Earth and Planetary Interiors, 87, 171-181.

Horvath, J.E., 2003. On gamma-ray bursts and their biological effects: A case for an extrinsic trigger for the Cambrian explosion? Astrophysical Abstracts, arXiv:astroph/0310034v1, 1-9.

Kirschvink, J.L. and Rozanov, A.Yu., 1984. Magnetostratigraphy of lower Cambrian strata from the Siberian platform: A paleomagnetic pole and a preliminary polarity time-scale, Geological Magazine, 121, 189-203.

Kirschvink, J.L., Magaritz, M., Ripperdan, R.L., Zhuralev, A. Yu., Rozanov, A. Yu., 1991. The Precambrian/Cambrian boundary: magnetostratigraphy and carbon isotopes resolve correlation problems between Siberia, Morocco and South China, GSA Today $1,69-71$.

Kirschvink, J.L., Ripperdan, R.L., Evans, D.A., 1997. Evidence for large-scale reorganization of early Cambrian continental masses by inertial interchange true polar wander. Science 277, 541-545. 
Knoll, A.H., 2011. The multiple origins of complex multicellularity, Annual Reviews of Earth and Planetary Sciences, 39, 217-239.

Knoll, A.H., Grotzinger, J.P., Kaufman, A.J., Kolosov, P., 1995. Integrated approaches to terminal Proterozoic stratigraphy: an example from the Olenek Uplift, northeastern Siberia. Precambrian Research, 73, 251-270.

Kolesnikov, A.V., Marusin, V.V., Nagovitsin, K.E., Maslov, A.V., Grazhdankin, D.V., 2015. Ediacaran biota in the aftermath of the Kotlinian crisis: Asha Group of the south Urals. Precambrian Research, 263, 59-78.

Kouchinsky, A, Bengtson, S., Gallet, Y., Korovnikov, I., Pavlov, V., Runnegar, B., Shields, G., Veizer, J., Young, E., Ziegler, K., 2008. The SPICE carbon isotope excursion in Siberia: A combined study of the upper Middle Cambrian-lowermost Ordovician Kuluyumbe River Section, northwestern Siberia platform, Geological Magazine, 145, 609-622.

Labrosse, S.., Poirer, J., LeMouel, J., 2001. The age of the inner core, Earth Planetary Science Letters, 190, 111-123.

Laflamme, M., Darroch, S.A.F., Tweedt, S.A., Peterson, K.J., Erwin, D.H., 2013. The end of the Ediacaran biota: biotic replacement or Cheshire cat?, Gondwana Research, 23, 558-573.

Landing, E, Myrow, P., Benus, A.P., Narbonne, G., 1989. The Placentian Series: appearance off the oldest skeletalized faunas in southeastern Newfoundland. Journal of Paleontology, 63, 739-769.

Landing, E., 2012. Time-specific black mudstones and global hyperwarming on the Cambrian-Ordovician slope and shelf of the Laurentia palaeocontinent. Palaeogeography, Palaeoclimatology, Palaeoecology, 367-368, 256-272.

Landing, E., Geyer, G., Bautois, L., 2015. Demonstrated long-term utility of the basal Cambrian GSSP at Fortune Head, eastern Newfoundland. Strati-Second international Congress on Stratigraphy. Berichte des Institut für Erdwissenschaften Karl-Franzen-Universität 21, 221.

Landing, E., Geyer, G., Brasier, M.D., Bowring, S.A., 2013. Cambrian Evolutionary Radiation: context, correlations, and chronostratigraphy-overcoming deficiencies of the first appearance datum (FAD) concept. Earth Science Reviews, 123, 133-177.

Landing, E., Westrop, S.R., 2004. Environmental patterns in the origin and diversification loci of early Cambrian skeletalized metazoan: Evidence from the Avalon microcontinent, Paleontology Papers 10, 93-106.

Lenton, T.M., Boyle, R.A., Poulton, S.W., Shields-Zhou, G.A., Butterfield, N.J., 2014. Coevolution of eukaryotes and ocean oxygenation in the Neoproterozoic era, Nature 
Geoscience, 7, 257-265.

Levashova, N.M., Bazhenov, M.L., Meert, J.G., Kuznetsov, N., Golovanova, I.V., Danukalov, K.N., Federova, N.M., 2013. Baltica in the end-Ediacaran: New paleomagnetic and geochronological data, Precambrian Research, 236, 16-30.

Lieberman, B.S. and Melott, A.L., 2007. Considering the case for biodiversity cycles: Re-examining the evidence for periodicity in the fossil record, PLOS One, doi:10.1371/journal.poe.0000759.

Llabres, M., Agusti, S., Fernandez, M., Canepa, A., Maurin, F., Vidal, F., Duarte, C.M., 2013. Impact of elevated UV-B radiation on marine biota: a meta-analysis, Global Ecology Biogeography, 22, 131-144.

Meert, J.G., 2014. Ediacaran-Ordovician Palaeomagnetism of Baltica: A review, Gondwana Research, 25, 159-169.

Meert, J.G. et al., 1993. A plate tectonic speed limit? Nature, 363, 216-217.

Meert, J.G., Lieberman, B.S., 2008. The Neoproterozoic Assembly of Gondwana and its relationship to the Ediacaran-Cambrian Radiation, Gondwana Research, 14, 5-21

Meert, J.G., Nedelec, A., Hall, C., Wingate, M., Rakotondrazafy, M., 2001.

Paleomagnetism, geochronology and tectonic implications of the Carion granite, central Madagascar, Tectonophysics, 340, 1-21.

Meert, J.G., Nedelec, A., Hall, C., 2003. The stratoid granites of central Madagascar: Paleomagnetism and further age constraints on Neoproterozoic deformation, Precambrian Research, 120, 101-129.

Meert, J.G., Tamrat, E., 2004. A mechanism for explaining rapid continental motion in the Late Neoproterozoic. In: Eriksson, et al. (Ed.), The Precambrian Earth: Tempos and Events, Developments in Precambrian Geology, 12. Elsevier, Amsterdam, 255266.

Meert, J.G., Van der Voo, R., 1996. Paleomagnetic and ${ }^{40} \mathrm{Ar} /{ }^{39} \mathrm{Ar}$ investigation of the Sinyai metadolerite, Kenya: Implications for Gondwana assembly, Journal of Geology, 104, 131-142.

Melott, A.L., Lieberman, B.S., Laird, C.M., Martin, L.D., Medvedev, M.V., Thomas, B.C., Cannizzo, J.K., Gehrels, N., Jackman, C.H., 2004. Did a gamma-ray burst initiate the Ordovician mass extinction?, International Journal of Astrobiology, 3, 55-61.

Nymmik, R.A., 2011. Some problems with developing a standard for determining solar energetic particle fluxes, Advances in Space Research, 47, 622-628. 
Pavlov, A.A., Pavlov, A.K., Mills, M.J., Ostrykov, V.M., Vasilyev, G.I. \& Toon, O.B., 2005. Catastrophic ozone loss during passage of the solar system through an interstellar cloud, Geophysical Research Letters, 32, doi:10.10129/2004GL021601.

Pavlov, V., Gallet, Y., 2000. Middle Cambrian high magnetic reversal frequency (Kulumber river section, northwest Siberia) and reversal behaviour during the Early Palaeozoic, Earth Planetary Science Letters, 185, 1-11.

Pavlov, V., Gallet, Y., 2005. A third superchron during the Early Palaeozoic, Episodes $28,1-7$.

Pétrélis, F., J. Besse, and J.-P. Valet, 2011. Plate tectonics may control geomagnetic reversal frequency, Geophysical Research Letters, 38, L19303, doi:10.1029/2011GL048784.

Phoenix, V.R., Konhauser, K.O., Adams, D.G., Bottrell, S.H., 2001. Role of biomineralization as an ultraviolet shield: Implications for Archean life, Geology, 19, 823-826.

Popov, V.V., Khramov, A.N., Bachtadse, V., 2005. Palaeomagnetism, magnetic stratigraphy, and palaeomagnetism of the Upper Vendian sedimentary rocks in the sections of the Zolotitsa River and in the Verkhotina borehole Winter Coast of the White Sea, Russia, Russian Journal of Earth Sciences, 7, 115-143.

Portmann, R.W., Daniel, J.S, Ravishankara,A.R., 2014. Stratospheric ozone depletion due to nitrous oxide: Influence of other gases, Philosophical Transactions Royal Society B, 367, 1256-1264.

Quintero-Torres, R., Arago, J.L., Torres, M., Estrada, M., Cruz, L., 2006. Strong far field coherent scattering of ultraviolet radiation by holococcolithophores, Physical Reviews Ecology, 74, doi:10.1103/PhysRevE.74.032901.

Rawlings, T.A., 1996. Shields against ultraviolet radiation: an additional protective role for the egg capsules of benthic marine gastropods, Marine Ecology Progress Series, 136, 81-95.

Riley, P., 2012, On the probability of occurrence of extreme space weather events, Space Weather, doi:10.1029/2011SW000734, 12 pp.

Rowland, S.M., Gangloff, R.A., 1988. Structure and paleoecology of lower Cambrian reefs, Palaios 3, 111-135.

Rozema, J., Bjorn, L.O., Bornman, J.F., Gaberscik, A., Hader, D.P., Trost, T., Germ, M., Klisch, M., Groniger, A., Sinha, R.P., Lebert, M., He, Y.Y., Buffoni-Hall, R., deBekker, 
N.J.J., van der Staaj, J., Meijkamp, B.B., 2002. The role of UV-B radiation in aquatic and terrestrial ecosystems-an experimental and functional analysis of the evolution of UV-absorbing compounds, Journal of Photochemistry and Photobiology-B, 66, 212.

Saltzman, M.R., Young, S.A., Kump, L.R., Gill, B.C., Lyons, T.W., Runnegar, B., 2011. Pulse of atmospheric oxygen during the late Cambrian, Proceedings of the National Academy of Sciences, 108, 3876-3881.

Shatsillo, A.V., N.B. Kuznetsov, M.A. Fedonkin, N.S.Priyatkina, Serov, S.G. (in press) First magnetostratigraphic data for the stratotype of the Upper Neoproterozoic Lopata Formation (the north-east Yenisei Ridge): problems of its age and paleogeography of the Siberian Platform at the boundary of the Phanerozoic and Proterozoic, Doklady Earth Sciences.

Shea, M.A., Smart, D.F., 2004. Preliminary study of cosmic rays, geomagnetic field changes and possible climate changes, Advances in Space Research, 34, 420-425.

Sigg, J.E., Lloyd-Knight, K.M. and Boal, J.G., 2007. UV radiation influences covering behaviour in the urchin Lytechnis variegatus, Journal of the Marine Biological Association U.K., 1257-1261.

Svensmark, H., 2006. Cosmic rays and the biosphere over 4 billion years, Astronmische Nachrichten, 327, 871-879.

Tauxe, L., Gee, J.S., Steiner, M.B., Staudiegel, H., 2013. Palaeointensity results from the Jurassic : New constraints from submarine basaltic glasses of ODP Site 801C, Geochemistry Geophysics Geosystems, 14, 4718-4733.

Tedetti, M. and Sempere, R., 2006. Penetration of ultraviolet radiation in the marine environment: A review, Photochemistry and Photobiology, 82, 389-397.

Valet, J.P., Meyadier, L., Guyodo, Y., 2005. Geomagnetic dipole strength over the past 2 million years, Nature 435, 802-805.

Vinebroke, R.D., Leavitt, P.R., 1999. Differential responses of littoral communities to ultraviolet radiation in an alpine lake, Ecology 80, 223-237.

Vogt, J., Zieger, B., Glassmer, K.H., Stadelmann, A., Kallenrode, M.B., Sinnhuber,M., Winkler, H., 2007. Energetic particles in the paleomagnetosphere: reduced dipole configurations and quadrupolar contributions, Journal of Geophysical Research-A, 112, doi:10.1029/2006JA012224. 
Wei, Y., Pu, Z., Zong, Q., Wan, W., Ren, Z., Fraenz, M., Dubin, E., Tian, F., Shi, Q., Fu, S., Hong, M., 2014. Oxygen escape from Earth during geomagnetic reversals:

Implications to mass extinctions, Earth Planetary Science Letters, 394, 94-98.

Winkler, H. et al., 2008. Modeling impacts of geomagnetic field variations on middle atmospheric ozone responses to solar proton events on long timescales, Journal of Geophysical Research, 113, doi:10.1026/2007JD008574.

Wood, B., Muller, H., Zank, G., Linsky, J., 2002. Measured mass-loss rates of solar-like stars as a function of age and activity, Astrophysical Journal, 574, 412-425.

Yin, J.Y., 2002. Research of paleomagnetism. in: Chen, L.X. et al. (eds) Early Cambrian Chengjiang fauna in eastern Yunnan, China, Science and Technology Press, Yunnan, 98-113 (in Chinese).

Xiao, S., Laflamme, M., 2008. On the eve of animal radiation: Phylogeny, ecology and evolution of the Ediacara biota, Trends in Ecology and Evolution, doi:10.1016/j.tree.2008.07.015.

Zhuravlev, A. Yu., Liñan, E., Gámez Vintaned, J. A., Debrenne, F., Fedorov, A. B., 2012. New finds of skeletal fossils in the terminal Proterozoic and of the Siberian Platform and Spain. Palaeontologica Polonica, 57, 205-226.

\section{FIGURES}

Figure 1: Major extinction/radiation pulses in the Ediacaran and Cambrian. The Ediacaran extinction coincides with the onset of magnetic field hyperactivity (MFH) at $550 \mathrm{Ma}$.

Figure 2: (a) Summary magnetostratigraphy for the Winter Coast sedimentary sequences (Zolotitsa region and Verkhotina borehole; Popov et al., 2005; (b) Magnetostratigraphy for the Zigan Formation of the Urals (Levashova et al., 2013). Ages are shown in the approximate stratigraphic position. Reversal rates in these sections are estimated to be more than 20 $\mathrm{RMa}^{-1}$.

Figure 3: (a) Summary magnetostratigraphy based on data for the Cambrian-Ordovician (Pavlov and Gallet, 2000; Gallet et al., 2003; Kouchinsky et al., 2008). Rapid reversal frequency of 6-10 RMa-1 are recorded in the 516-497 Ma interval followed by a decline in reversal rates in the Furongian $(\sim 497 \mathrm{Ma})$. (b) Modeled atmospheric $\mathrm{O}_{2}$ based on isotopic mass balance and $\mathrm{O}_{2}$-dependent photosynthetic fractionation during the SPICE positive $\delta^{13} \mathrm{C}$ anomaly and the end of magnetic field hyperactivity in the Furongian (ages re-calibrated to the 2012 time scale; Saltzman et al., 2011).

Figure 4: (a) This figure shows $\mathrm{O}^{+}$escape from a planet dominated by an axial quadrupole dominated planet (such as the Earth during a reversal). The red arrows indicate $\mathrm{O}^{+}$ dominated ionosphere, AW=auroral zones on a quadrupolar planet; MT region is the area of momentum transfer where solar wind imparts enough energy that $\mathrm{O}^{+}$ions can 
gravitationally escape. The auroral wind regions can also serve to deliver $\mathrm{O}^{+}$ions to higher altitudes particularly during solar events that deliver a higher particle flux into the upper atmosphere (Wei et al., 2014; modified from original publication) (b) Diagram of the Earth (blue) during a reversal or weaker dipole where solar particle emission (SPEs) and gamma ray burst particles (GRB's) and anomalous components of galactic rays (ACRs) interact with $\mathrm{NO}_{x}$ to eliminate $\mathrm{O}_{3}$ from the upper atmosphere.

Figure 5: (a) Reversal frequency from Ediacaran to present-day. The Ediacaran reversal rate is estimated to be 2-3x higher than recorded in the Phanerozoic (Biggin et al., 2012). (b) Schematic model of magnetic field behavior showing a ramp-decay process leading from hyperactive intervals into superchrons. 


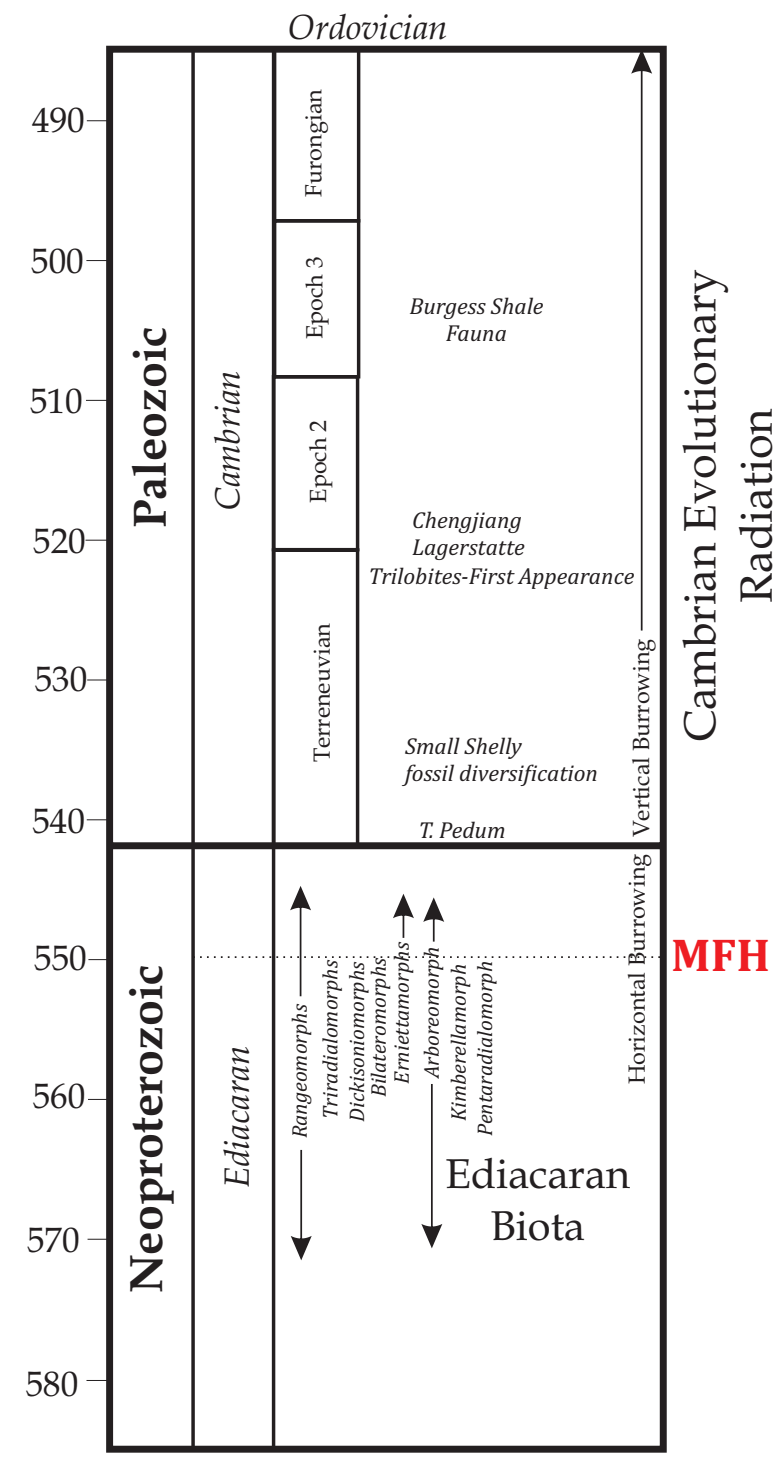




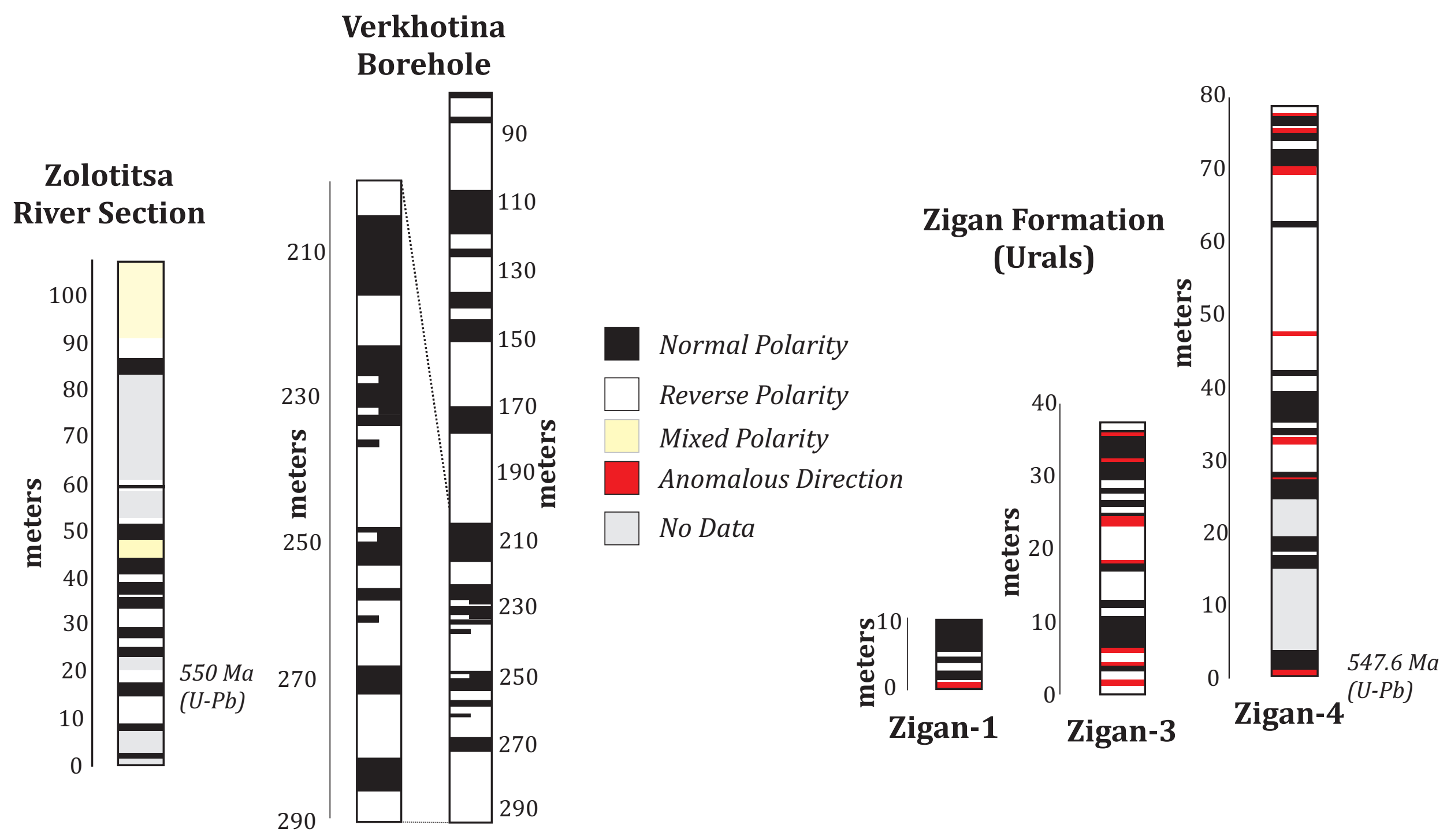

(a) 
(a)

Composite

Pavlov \& Gallet (2005)

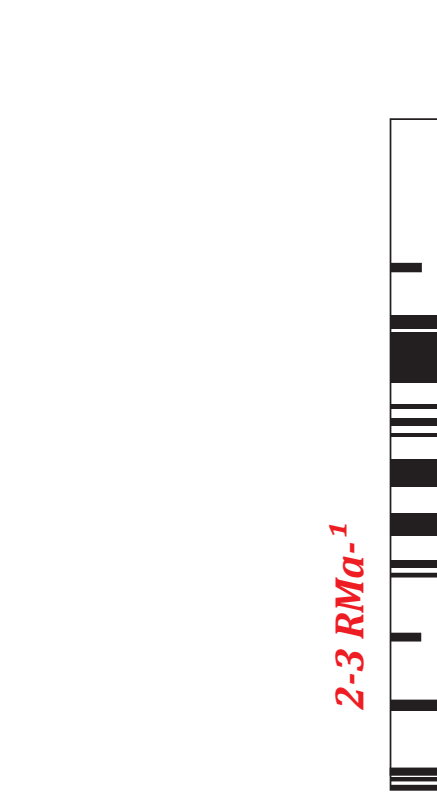

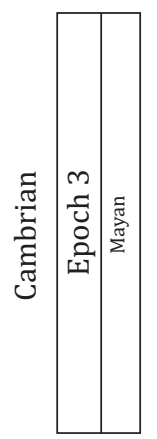

Kulumbe

Section Section

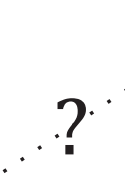

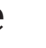

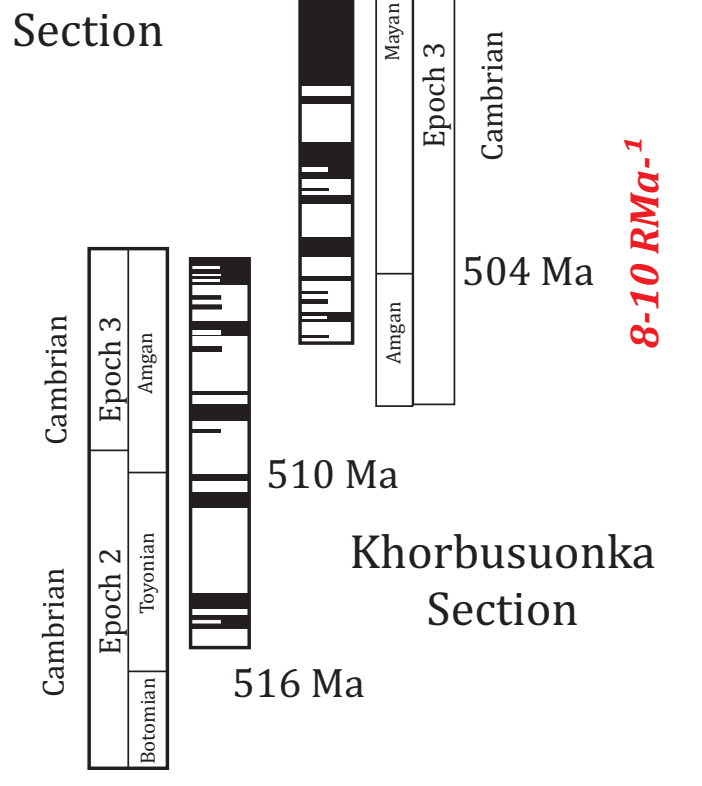

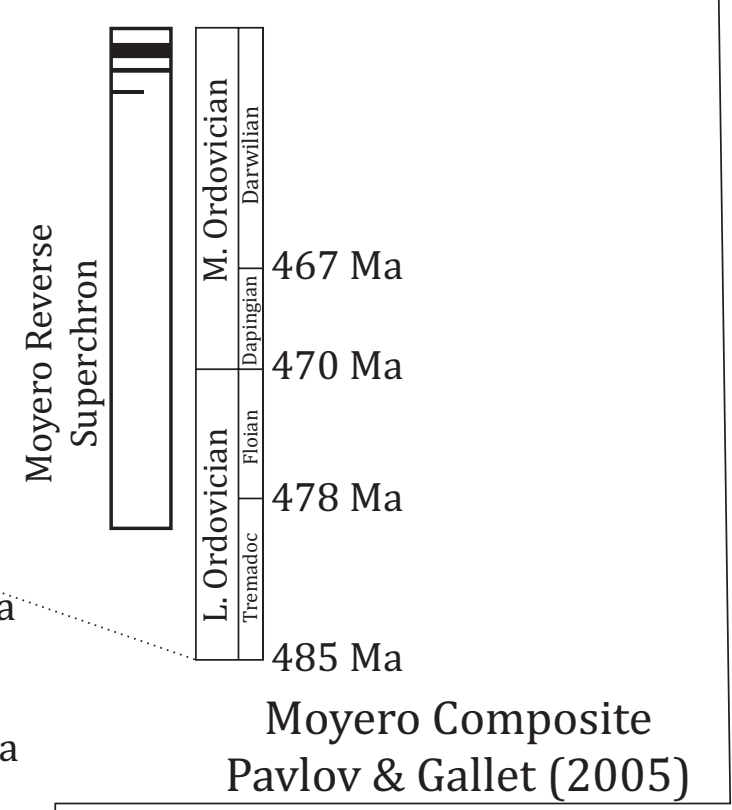

$492.5 \mathrm{Ma}$

$497 \mathrm{Ma}$

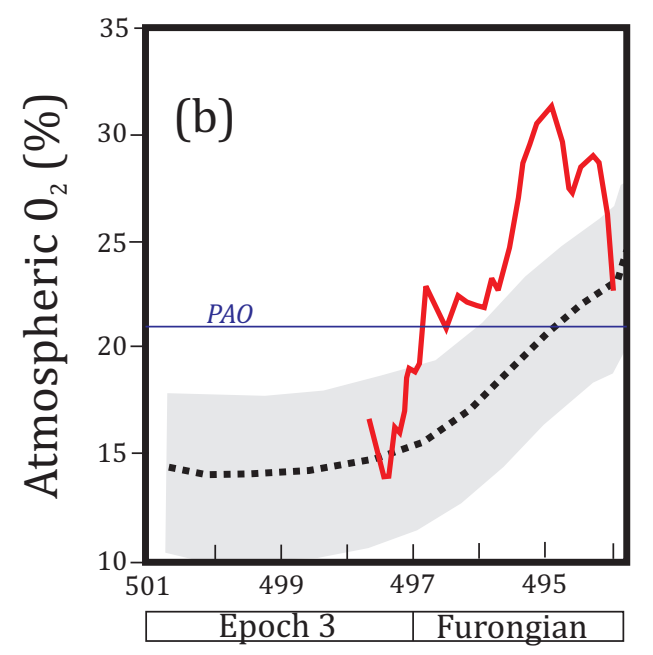

Cambrian-Ordovician Magnetostratigraphy

Normal Polarity

$\square$ Reverse Polarity 


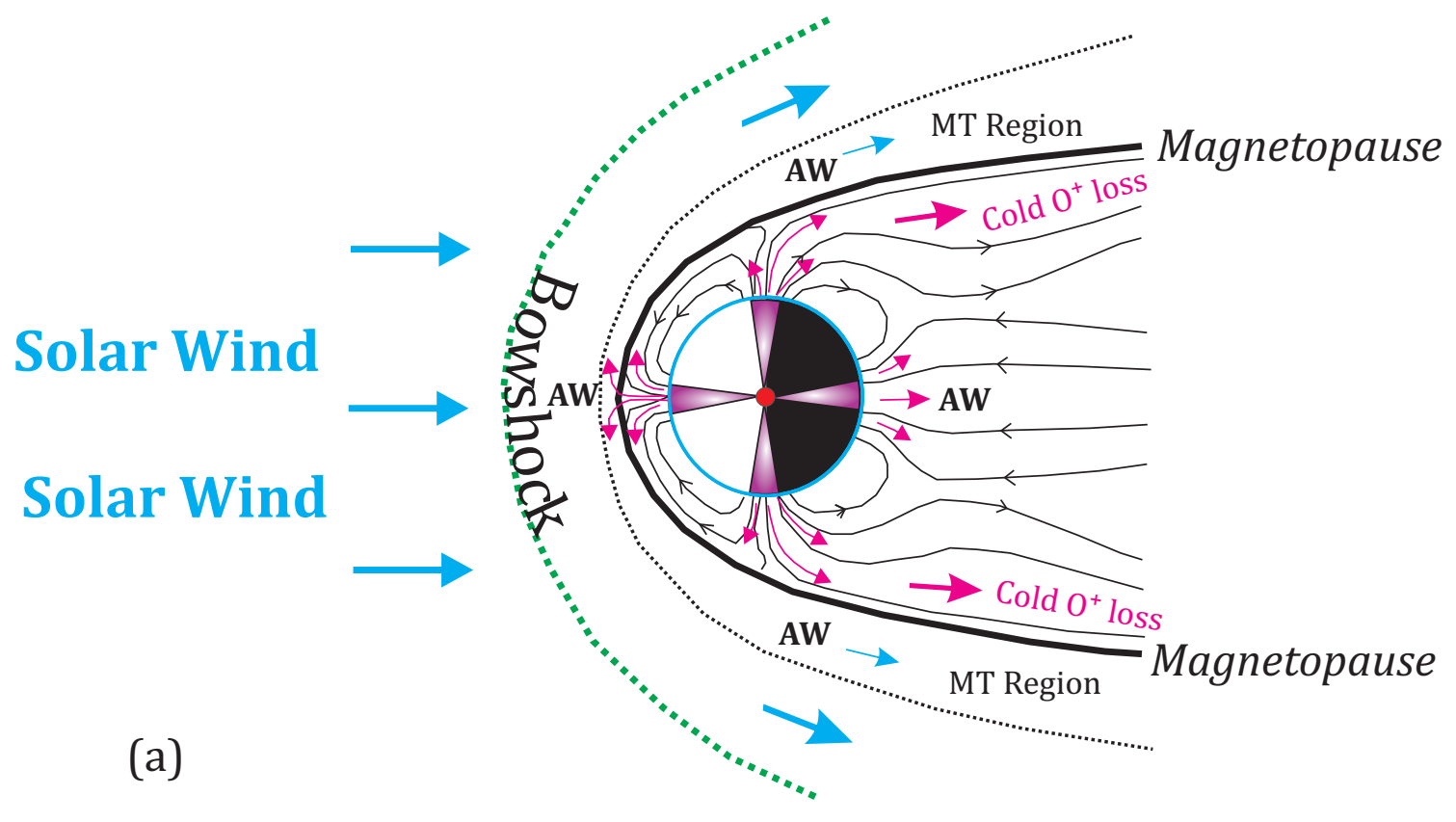

b)

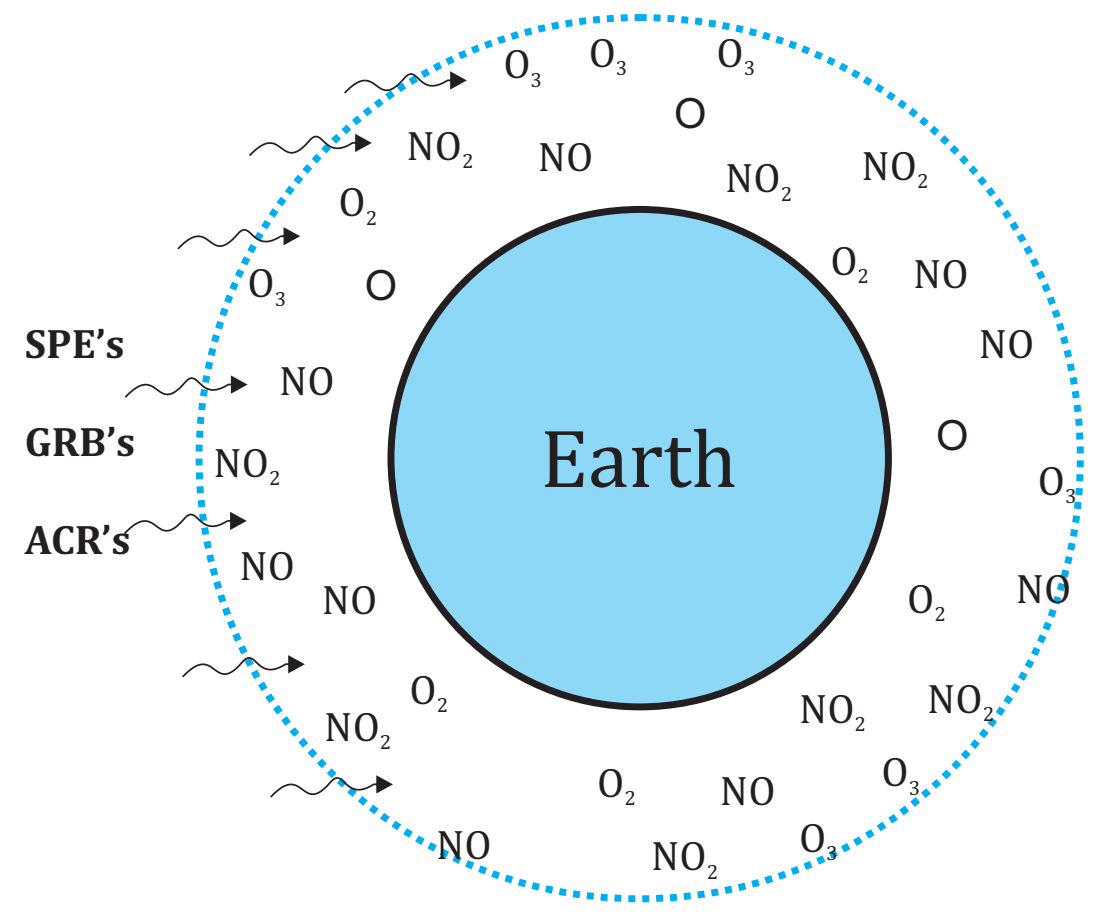

$$
\mathrm{NO}_{2}+\mathrm{O}---->\mathrm{NO}+\mathrm{O}_{3}---->\mathrm{NO}_{2}+\mathrm{O}_{2}
$$

(Ozone Photochemical Reaction) 

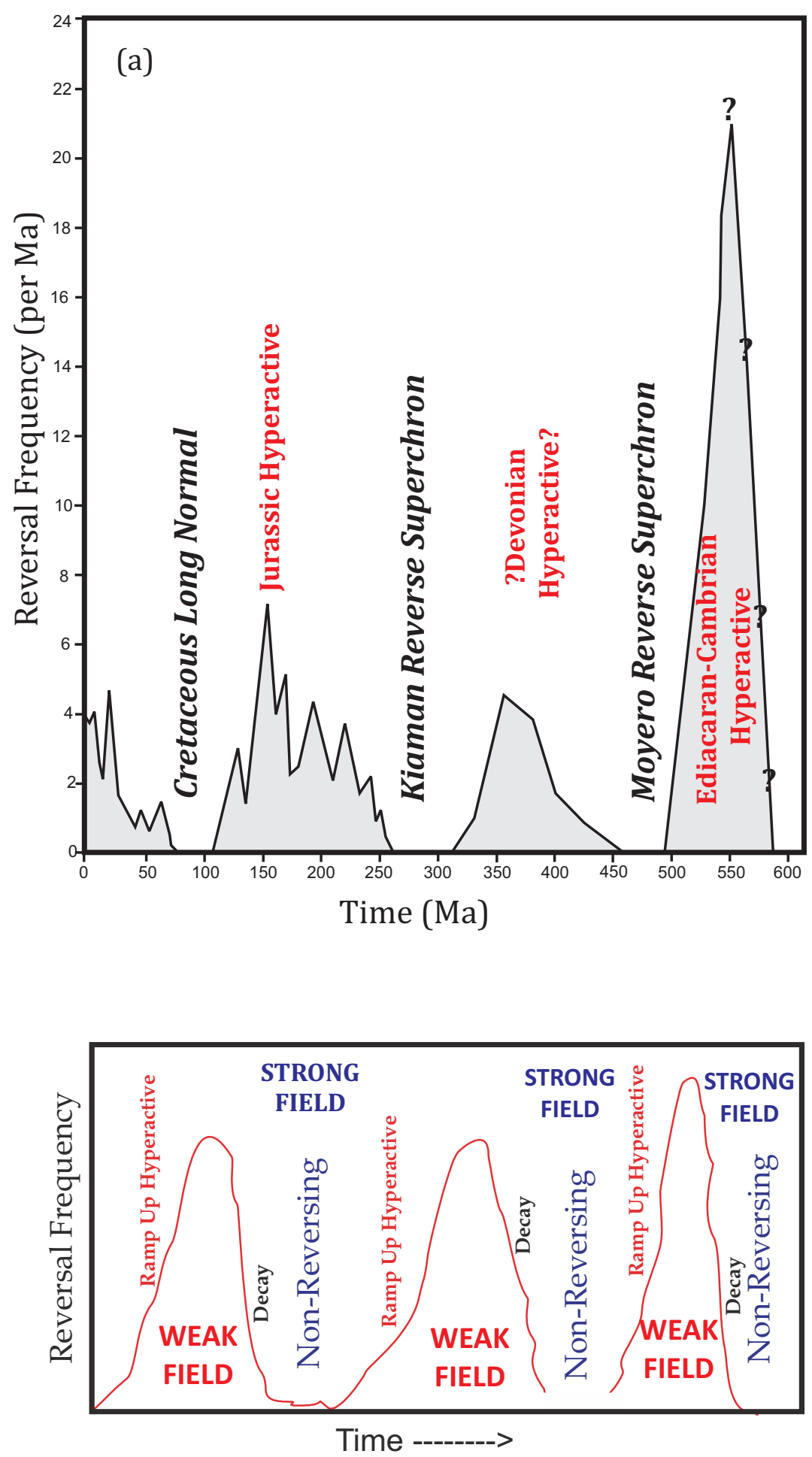

(b) 


\section{A Series of Unfortunate/Fortunate Events}

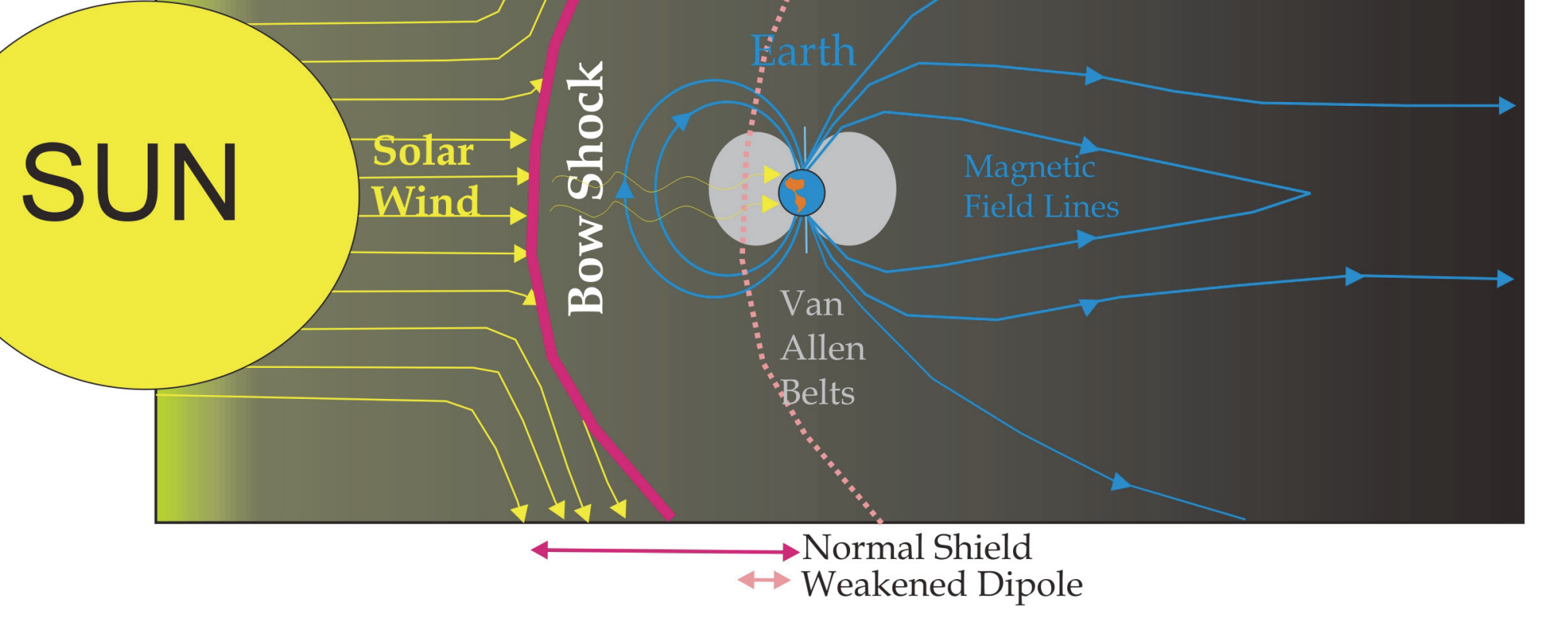

High Magnetic Reversal Rate

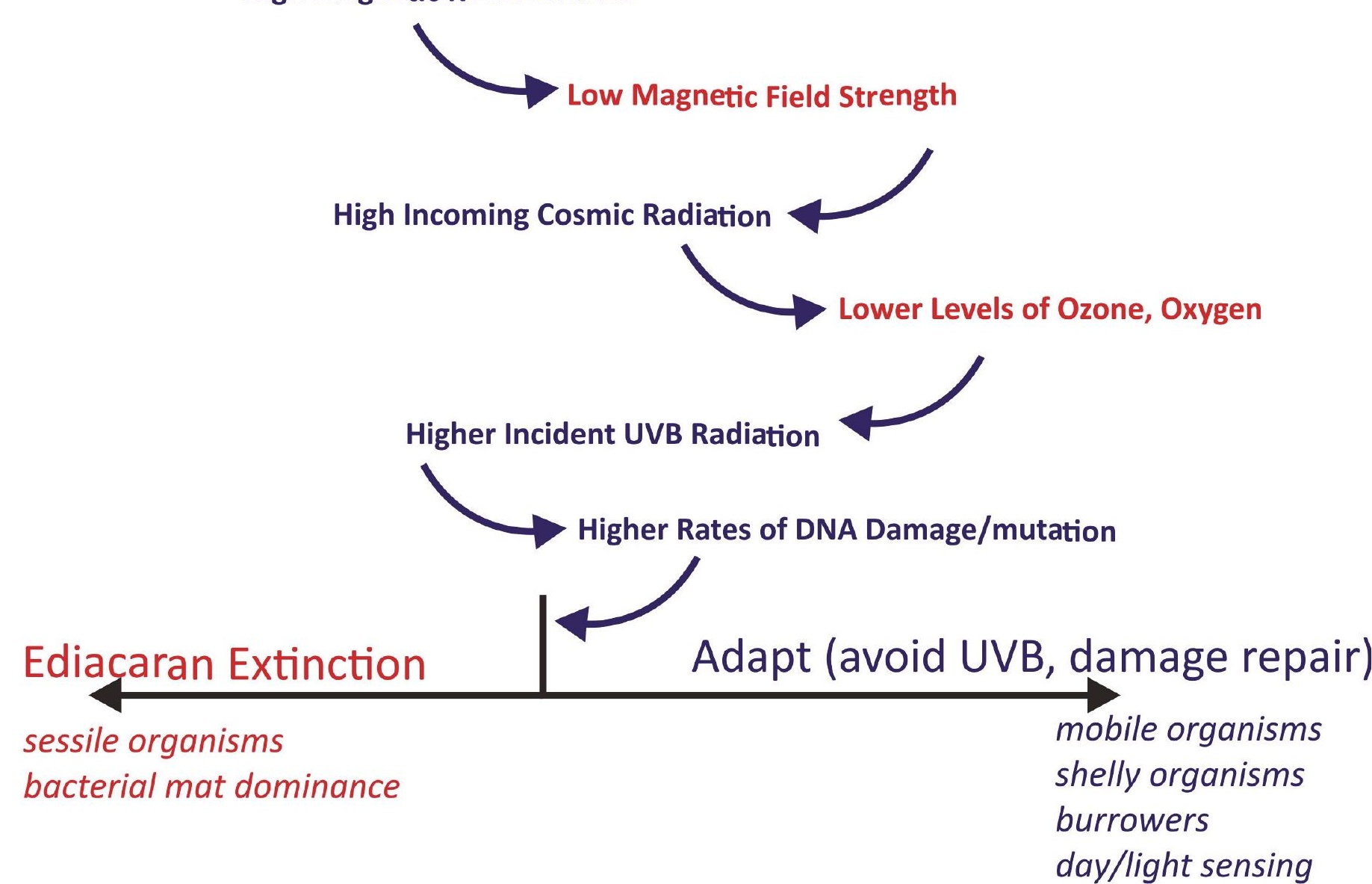

